\title{
HIKMAH DIBALIK KAEDAH DUA BANDING SATU PADA HUKUM WARISAN
}

\author{
Nurhadi \\ Sekolah Tinggi Agama Islam (STAI) Al-Azhar Pekanbaru Riau \\ Email: alhadijurnal@gmail.com; alhadicentre@yahoo.co.id
}

\begin{abstract}
:
The principle of balanced justice in Islamic inheritance law dictates that men and women are equally entitled to appear as heirs, with different forms. Based on the qath'i text, the just and balanced means in the Islamic inheritance law is that the male portion is equal to the share of two women (2: 1 for male and female). The difference in costs is not due to gender issues, but rather the differences in duties and responsibilities imposed on men are greater than those imposed on women in the context of Islamic society, according to conventional standard theory which states: "The greater and heavier the burden is men, the greater the rights that will be obtained ", due to the costs that must be incurred to carry out greater responsibilities.
\end{abstract}

Keywords: Wisdom, Method, Two Appeal One, Inheritance Law.

\begin{abstract}
Abstrak:
Azas keadilan berimbang dalam hukum waris Islam menentukan laki-laki dan perempuan sama-sama berhak tampil sebagai ahli waris, dengan forsi yang berbeda. Berdasarkan nash yang qath'i, maka adil dan berimbang yang dimaksudkan dalam hukum waris Islam adalah bagian laki-laki sama dengan bagian dua orang perempuan (forsi 2:1 antara laki-laki dan perempuan). Perbedaan forsi tersebut tidak disebabkan persoalan gender, melainkan atas perbedaan tugas dan tanggung jawab yang dibebankan kepada laki-laki lebih besar dibandingkan dengan yang dibebankan kepada perempuan dalam konteks masyarakat Islam, sesuai teori standar konvensional yang menyebutkan: "Semakin besar dan berat beban yang dipikul seorang laki-laki, maka semakin besar pula hak yang akan diperolehnya", disebabkan biaya yang harus dikeluarkannya untuk mengemban tanggung jawab yang lebih besar.
\end{abstract}

Kata Kunci: Hikmah, Kaedah, Dua Banding Satu, Hukum Warisan.

\section{PENDAHULUAN}

Sebagai agama yang sempurna, Islam mengatur segala sisi kehidupan manusia, bahkan dalam hal yang berkaitan dengan peralihan harta yang ditinggalkan seorang manusia, setelah manusia tersebut meninggal dunia. Hukum yang membahas tentang peralihan harta tersebut dalam ilmu hukum disebut hukum kewarisan, atau dikenal juga dengan hukum faraid. ${ }^{1}$

Idris Djakfar dan Taufik Yahya mendifinisikan bahwa hukum kewarisan ialah seperangkat ketentuan yang mengatur cara-cara peralihan hak dari seseorang yang telah

\footnotetext{
${ }^{1}$ M. Mawardi Djalaluddin, Nilai-Nilai Keadilan dalam Harta Warisan Islam, (Jurnal VolumeV,Nomor1, Januari-Juni, 2017), hlm. 109
} 
meninggal dunia kepada orang yang masih hidup yang ketentuan-ketentuan tersebut berdasarkan pada wahyu Ilahi yang terdapat dalam al-Qur'an dan penjelasannya yang diberikan oleh Nabi Muhammad saw, dalam istilah arab disebut Faraidl. ${ }^{2}$

Dari kedua definisi tersebut dapat diketahui bahwa hukum kewarisan Islam merupakan hukum yang mengatur tentang peralihan kepemilikan harta dari orang yang telah meninggal dunia kepada orang yang masih hidup (yang berhak menerimanya), yang mencakup apa saja yang menjadi harta warisan, siapa-siapa saja yang berhak menerima, berapa besar forsi atau bagian masing-masing ahli waris, kapan dan bagaimana tata cara pengalihannya. Warisan menurut sebagian besar ahli hukum Islam ialah semua harta benda yang ditinggalkan oleh seseorang yang meninggal dunia baik berupa benda bergerak maupun benda tetap, termasuk barang/uang pinjaman dan juga barang yang ada sangkut pautnya dengan hak orang lain, misalnya barang yang digadaikan sebagai jaminan atas hutangnya ketika pewaris masih hidup. ${ }^{3}$

Allah Swt. memerintakan agar setiap orang yang beriman mengikuti ketentuanketentuan Allah menyangkut hukum kewarisan sebagaimana yang termaktub dalam kitab suci Al-Qur'an dan menjanjikan siksa neraka bagi orang yang melanggar peraturan ini. ${ }^{3}$ Dalam Q.S. an-Nisa' ayat 13 dan 14 Allah berfirman:

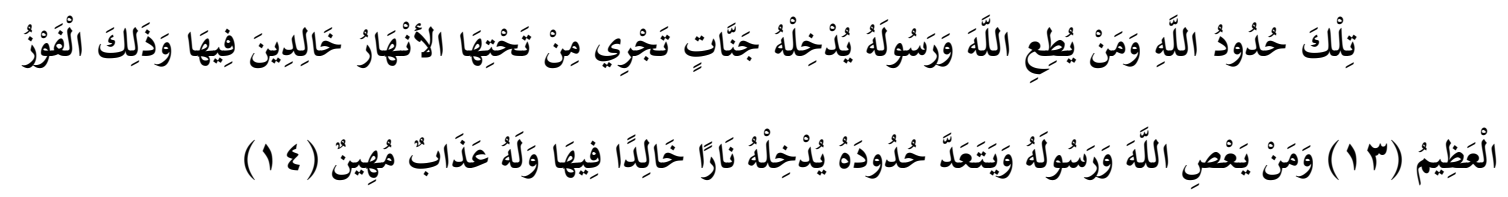

Artinya: (Hukum-hukum tersebut) itu adalah ketentuan-ketentuan dari Allah. Barangsiapa taat kepada Allah dan Rasul-Nya, niscaya Allah memasukkannya kedalam syurga yang mengalir didalamnya sungai-sungai, sedang mereka kekal di dalamnya; dan Itulah kemenangan yang besar. Dan Barangsiapa yang mendurhakai Allah dan RasulNya dan melanggar ketentuan-ketentuan-Nya, niscaya Allah memasukkannya ke dalam api neraka sedang ia kekal di dalamnya; dan baginya siksa yang menghinakan. ${ }^{4}$

Ayat tersebut merupakan ayat yang mengiringi hukum-hukum Allah menyangkut penentuan para ahli waris, tahapan pembagian warisan serta forsi masingmasing ahli waris, yang menekankan kewajiban melaksanakan pembagian warisan

\footnotetext{
${ }^{2}$ Idris Djakfar dan Taufik Yahya, Kompilasi Hukum Kewarisan Islam (Jakarta; PT. Dunia Pustaka Jaya, 2015), hlm. 3-4

${ }^{3}$ Masjfuk Zuhdi, Studi Islam, Jilid III, (Jakarta: PT. Raja Grafindo, 2013), hlm. 57

${ }^{4}$ Departemen Agama RI, Al-Qur'an dan Terjemahanya, (Semarang: Toha Putra, 2015), hlm. 118
} 
sebagaimana yang ditentukan Allah, yang disertai ancaman bagi yang melanggar ketentuan tersebut. Sebaliknya bagi hamba yang mengikuti ketentuanNya, Allah menjanjikan surga. Rasulullah Saw. bersabda: "Barangsiapa yang tidak menerapkan hokum waris yang telah diatur Allah swt, maka ia tidak akan mendapat warisan surge”. (HR. Bukhari Muslaim). ${ }^{5}$

Dalam tradisi Arab pra Islam, hukum yang diberlakukan menyangkut ahli waris mereka menetapkan bahwa wanita dan anak-anak tidak memperoleh bagian warisan, dengan alasan mereka tidak atau belum dapat berperang guna mempertahankan diri, suku atau kelompoknya, ${ }^{6}$ oleh karena itu yang berhak mewarisi adalah laki-laki yang berfisik kuat dan dapat memanggul senjata untuk mengalahkan musuh dalam setiap peperangan. ${ }^{7}$ Konsekwensinya perempuan, anak-anak dan orang tua renta tidak berhak mewarisi harta peninggalan kerabatnya.

Islam datang membawa panji keadilan persamaan kedudukan laki-laki dan perempuan, anak-anak, orang dewasa, orang yang tua renta, suami, isteri saudara lakilaki dan saudara perempuan sesuai tingkatan masing-masing. Dari berbagai ketentuan dalam hukum kewarisan Islam, setidaknya ada lima azas (doktrin) yang disepakati sebagai sesuatu yang dianggap menyifati hukum kewarisan Islam, yaitu bersifat Ijbari, bilateral, individual, keadilan yang berimbang dan akibat kematian. ${ }^{8}$

Bertolak dari uraian latar belakang di atas, maka penulis perlu memberikan batasan-batasan dalam tulisan ini. Makalah ini membahas tentang "bagaimana nilai keadilan dalam hukum waris Islam tentang dua banding satu bagi laki-laki dan perempuan?.

\section{KEADILAN DALAM HUKUM WARIS ISLAM}

Sebagaimana yang telah dikemukakan terdahulu bahwa keadilan merupakan salah satu asas (doktrin) dalam hukum waris Islam, yang disimpulkan dari kajian mendalam tentang prinsip-prinsip dasar yang terkandung dalam hukum tentang

\footnotetext{
${ }^{5}$ M. Mawardi Djalaluddin, Nilai-Nilai Keadilan dalam Harta Warisan Islam, hlm. 111

${ }^{6}$ Muhammad Ali Ash-Shabuni, Ilmu Hukum Waris Menurut Ajaran Islam, (Surabaya: Mutiara Ilmu, t.th.), hlm. 15

${ }^{7}$ Ahmad Rofik, Fiqh Mawaris, (Jakarta: PT. Raja Grafindo Persada, 2015), hlm. 6

${ }^{8}$ Amir Syarifuddin, Pelaksanaan Hukum Kewarisan Islam dalam Lingkungan Adat Minangkabau,

(Jakarta: PT. Gunung Agung, 2014), hlm. 24
} 
kewarisan. Hal yang paling menonjol dalam pembahasan tentang keadilan menyangkut hukum Kewarisan Islam adalah tentang hak sama-sama dan saling mewarisi antara lakilaki dan perempuan serta perbandingan $2: 1$ (baca 2 banding 1) antara forsi laki-laki dan perempuan. ${ }^{9}$

Asas keadilan dalam hukum Kewarisan Islam mengandung pengertian bahwa harus ada keseimbangan antara hak yang diperoleh dan harta warisan dengan kewajiban atau beban kehidupan yang harus ditanggungnya/ditunaikannya diantara para ahli waris ${ }^{10}$ karena itu arti keadilan dalam hukum waris Islam bukan diukur dari kesamaan tingkatan antara ahli waris, tetapi ditentukan berdasarkan besar-kecilnya beban atau tanggungjawab diembankan kepada mereka, ditinjau dari keumuman keadaan/kehidupan manusia. Jika dikaitkan dengan definisi keadilan yang dikemukakan Amir Syarifuddin sebagai "keseimbangan antara hak dan kewajiban dan keseimbangan antara yang diperoleh dengan keperluan dan kegunaan", ${ }^{11}$ atau perimbangan antara beban dan tanggung jawab diantara ahli waris yang sederajat, maka kita akan melihat bahwa keadilan akan nampak pada pelaksanaan pembagian harta warisan menurut Islam. ${ }^{12}$

Rasio perbandingan 2 : 1, tidak hanya berlaku antara anak laki-laki dan perempuan saja, melainkan juga berlaku antara suami isteri, antara bapak-ibu serta antara saudara lelaki dan saudara perempuan, ${ }^{13}$ yang kesemuanya it u mempunyai hikmah apabila dikaji dan diteliti secara mendalam. ${ }^{14}$

Dalam kehidupan masyarakat muslim, laki-laki menjadi penanggung jawab nafkah untuk keluarganya, berbeda dengan perempuan. Apabila perempuan tersebut berstatus gadis/masih belum menikah, maka ia menjadi tanggung jawab orang tua ataupun walinya ataupun saudara laki-lakinya. Sedangkan setelah seorang perempuan menikah, maka ia berpindah akan menjadi tangguag jawab suaminya (laki-laki).

\footnotetext{
${ }^{9}$ M. Mawardi Djalaluddin, Nilai-Nilai Keadilan dalam Harta Warisan Islam, hlm. 112

${ }^{10}$ Ahmad Zahari, Tiga Versi Hukum Kewarisan Islam: Syafi'i, Hazairin dan KHI, (Pontianak: Romeo Grafika, 2013), hlm. 25

${ }^{11}$ Juga merupakan salah setu intisari kuliah perdana Capita Selekta Hukum IslamMagister Ilmu Hukum Semester IV, Universitas Muhammadiyah Jakarta yang disampaikan Prof. DR. H. Abdullah Syah, MA tanggal 2 April 2005 di Kampus UMSU-Medan.

${ }^{12}$ M. Mawardi Djalaluddin, Nilai-Nilai Keadilan dalam Harta Warisan Islam, hlm. 112

${ }^{13}$ Cholil Umam, Agama Menjawab Tantangan Berbagai Masalah Abad Modern, Surabaya: Ampel Suci, 2014), hlm. 101.

${ }^{14}$ Masjfuk Zuhdi, Masail Fiqhyah, (Jakarta: PT. Gunung Agung, 2017), hlm. 207
} 
Syari'at Islam tidak mewajibkan perempuan untuk menafkahkan hartanya bagi kepentingan dirinya ataupun kebutuhan anak-anaknya, meskipun is tergolong mampu/kaya, jika ia telah bersuami, ${ }^{11}$ sebab memberi nafkah (tempat tinggal, makanan dan pakaian) keluarga merupakan kewajiban yang dibebankan syara' kepada suami (lakilaki setelah ia menikah). Dalam QS. At-Thalaq ayat 6 Allah berfirman:

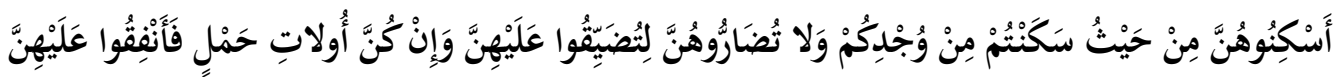

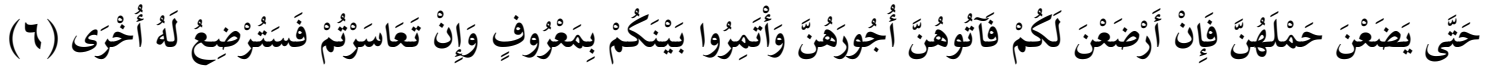

Artinya: Tempatkanlah mereka (para isteri) di mana kamu bertempat tinggal menurut kemampuanmu dan janganlah kamu menyusahkan mereka untuk menyempitkan (hati) mereka. dan jika mereka (isteri-isteri yang sudah ditalaq) itu sedang hamil, Maka berikanlah kepada mereka nafkahnya hingga mereka bersalin, kemudian jika mereka menyusukan (anak-anak)mu untukmu Maka berikanlah kepada mereka upahnya, dan musyawarahkanlah di antara kamu (segala sesuatu) dengan baik; dan jika kamu menemui kesulitan Maka perempuan lain boleh menyusukan (anak itu) untuknya. ${ }^{15}$

Dalam QS. Al- Baqarah ayat 233 Allah berfirman:

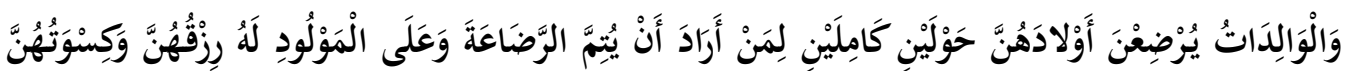

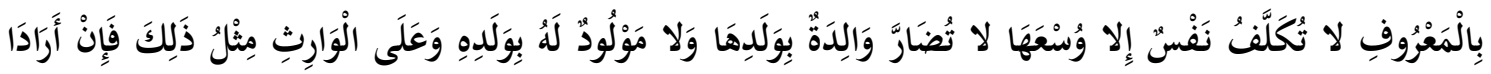

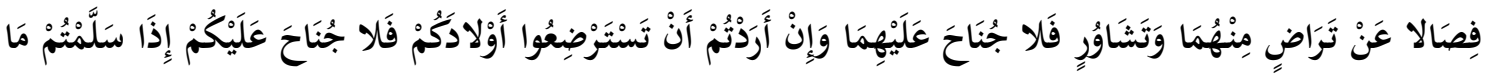

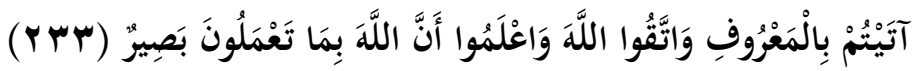

Artinya: Para ibu hendaklah menyusukan anak-anaknya selama dua tahun penuh, Yaitu bagi yang ingin menyempurnakan penyusuan. dan kewajiban ayah memberi Makan dan pakaian kepada Para ibu dengan cara ma'ruf. seseorang tidak dibebani melainkan menurut kadar kesanggupannya. janganlah seorang ibu menderita kesengsaraan karena anaknya dan seorang ayah karena anaknya, dan warispun berkewajiban demikian. apabila keduanya ingin menyapih (sebelum dua tahun) dengan kerelaan keduanya dan permusyawaratan, Maka tidak ada dosa atas keduanya. dan jika kamu ingin anakmu disusukan oleh orang lain, Maka tidak ada dosa bagimu apabila kamu memberikan pembayaran menurut yang patut. bertakwalah kamu kepada Allah dan ketahuilah bahwa Allah Maha melihat apa yang kamu kerjakan. ${ }^{16}$

Pasal 34 ayat (1) UU Nomor 1 Tahun 1974 menyatakan: "Suami wajib

\footnotetext{
${ }^{15}$ Departemen Agama RI, Al-Qur'an dan Terjemahanya, hlm. 946

${ }^{16}$ Departemen Agama RI, Al-Qur'an dan Terjemahanya, hlm. 57
} 
melindungi isterinya dan memberikan segala sesuatu keperluan hidup berumah tangga sesuai dengan kemampuannya". ${ }^{17}$ Sedangkan kewajiban isteri pada dasarnya adalah mengatur urusan intern rumah tangga dengan sebaik-baiknya. ${ }^{18}$ Hal demikian juga berlaku dalam kedudukan sebagai ayah dan ibu pewaris. ${ }^{19}$

Dalam tingkatan anak, anak laki-laki yang belum menikah, ia diwajibkan memberi mahar ${ }^{20}$ dan segala persyaratan pernikahan yang dibebankan pihak keluarga calon isteri kepadanya. Setelah menikah, maka beban menafkahi isteri (dan anakanaknya) kelak akan diletakkan dipundaknya. ${ }^{21}$

Sebaliknya anak perempuan, dengan forsi yang diperolehnya tersebut akan mendapat penambahan dari mahar yang akan didapatkannya apabila kelak ia menikah, selanjutnya setelah menikah ia (pada dasarnya) tidak dibebankan kewajiban menafkahi keluarganya, bahkan sebaliknya dia akan menerima nafkah dari suaminya, kondisi umum ini tidak menafikan keadaan sebaliknya, tapi jumlahnya tidak banyak. ${ }^{22}$

Dari penjelasan tersebut, jika dicontohkan secara konkrit adalah seorang anak laki-laki memperoleh harta warisan bernilai uang Rp.20.000.000,- (dua puluh juta), sedangkan saudara perempuannya memperoleh Rp.10.000.000; (sepuluh juta) berdasarkan ketentuan 2 : 1, maka ketika laki-laki tersebut akan menikah, ia akan mengeluarkan biaya keperluan mahar sekitar Rp.5.000.000,- (lima juta rupiah), jadi sisa harta dari bagian warisan yang ada pada laki-laki tersebut berjumlah Rp.15.000.000; (lima belas juta rupiah). Sebaliknya saudara perempuannya yang memperoleh bagian warisan Rp.10.000.000; (sepuluh juta rupiah) tersebut akan memperoleh tambahan Rp.5.000.000,- (lima juta rupiah) disebabkan mahar yang diperolehnya dari laki-laki yang menikah dengannya. Dengan demikian maka kedua-duanya (laki-laki dan perempuan) yang memperoleh bagian warisan tersebut sama-sama memperoleh

\footnotetext{
${ }^{17}$ Bunyi dan maksud yang sama juga terdapat dalam Pasal 80 ayat (1) Kompilasi Hukum Islam. Sedangkan pada Pasal 80 ayat (4) KHI diuraikan tentang kewajiban suami memberi nafkah, kiswah, maskan, biaya kebutuhan rumah tangga, pendidikan anak dan biaya kesehatan, sesuai dengan kemampuan suami. ${ }^{18}$ Pasa134 ayat (2) UU Nomor 1 Tahun 1974 jo Pasal 83 ayat (2) KHI.

${ }^{19}$ Sayuti Thalib, Hukum Kewarisan Islam Di Indonesia, (Jakarta: Sinar Grafindo, 2015), hlm. 119.

${ }^{20}$ Pasal $30 \mathrm{KHI}$ menyebutkan: "Calon mempelai pria wajib membayar mahar kepada calon mempelai wanita, yang jumlah, bentuk dan jenisnya disepakati oleh kedua belah pihak".

${ }^{21}$ M. Mawardi Djalaluddin, Nilai-Nilai Keadilan dalam Harta Warisan Islam, hlm. 113

${ }^{22}$ M. Mawardi Djalaluddin, Nilai-Nilai Keadilan dalam Harta Warisan Islam, hlm. 113
} 
Rp.15.000.000,- (lima belas juta rupiah) ${ }^{23}$

Dengan demikian maka perempuan selain pemilik penuh dari kekayaan yang diwarisi dari orang tuanya dan tidak ada pemaksaan/kewajiban untuk dibelanjakan, juga akan mendapatkan tambahan dari mahar yang diberikan laki-laki yang akan menjadi suaminya serta mendapatkan hak nafkah dari suaminya tersebut. ${ }^{24}$

Hal demikian menunjukkan bahwa keadilan dalam hukum waris Islam bukan saja keadilan yang bersifat distributif semata (yang menentukan besarnya forsi berdasarkan kewajiban yang dibebankan dalam keluarga), akan tetapi juga bersifat commulatif, yakni bagian warisan juga diberikan kepada wanita dan anak-anak. Hal tersebut berbeda dengan hukum warisan Yahudi, Romawi dan juga hukum adat pra Islam, bahkan sebagiannya hingga sekarang masih berlaku. ${ }^{25}$

Jika dalam satu kasus seorang anak (juga saudara) perempuan mendapat separuh dari harta peninggalan, pada hakikatnya jauh lebih besar dari perolehan laki-laki, sebab kekayaan laki-laki (termasuk dari bagian warisan) pada akhirnya akan pindah ke tangan wanita dalam bentuk pangan, sandang dan papan, sehingga bahagian laki-laki tersebut akan lebih dahulu habis. Sebaliknya kekayaan perempuan (dari pembagian warisan tersebut) akan tetap utuh tak berkurang, jika diinginkannya, ${ }^{26}$ karena pada hakikatnya perempuan mengambil bagian (warisan, harta laki-laki) dan tidak memberi apa-apa, Ia mendapat bagian warisan dan memperoleh nafkah, tidak sebaliknya. ${ }^{27}$

Perbedaan yang berdasarkan besar kecilnya beban dan tanggung jawab laki-laki dan perempuan sebagaimana diuraikan di atas, berdasar hukum kausalitas imbalan dan tanggung jawab, bukan mengandung unsur diskriminasi. Forsi perempuan yang ditentukan tersebut seimbang dengan kewajibannya. Sebab dalam Islam, kaum wanita pada dasarnya dibebaskan dari memikul tanggungjawab ekonomi keluarga. Oleh karena itu, jika seseorang menerima bagian waris tinggi, berarti hal itu merupakan manifestasi dari tingkat kewajibannya, yang merupakan konsep perbedaan secara sosiologis dalam

\footnotetext{
${ }^{23}$ M. Mawardi Djalaluddin, Nilai-Nilai Keadilan dalam Harta Warisan Islam, hlm. 114

${ }^{24}$ M. Mawardi Djalaluddin, Nilai-Nilai Keadilan dalam Harta Warisan Islam, hlm. 114

${ }^{25}$ Muhammad Amin Summa, Hukum Keluarga Islam di Dunia Islam, (Jakarta: PT. RajaGrafindo Persada, 2014), hlm. 124-125

${ }^{26}$ Nashruddin Baidan, tafsir bi al-Ra yi, (Yogyakarta: Pustaka Pelajar, 2009), hlm. 65

${ }^{27}$ M. Mawardi Djalaluddin, Nilai-Nilai Keadilan dalam Harta Warisan Islam, hlm. 115
} 
masyarakat Islam. ${ }^{28}$

Di Indonesia pernah dikemukakan wacana yang menyatakan perbandingan $2: 1$ bukan ketentuan yang bersifat pasti dan tetap, sehingga dapat dikompromikan, diantaranya Zainuddin Sardar yang menyatakan bahwa setiap rumusan hukum yang terdapat pada nash Al-Qur' an dan Hadits terdiri dari unsur-unsur : a). Unsur Normatif yang bersifat abadi dan universal, berlaku untuk semua tempat dan waktu serta tidak berubah dan tidak dapat diubah. b). Unsur Hudud yang bersifat elastis sesuai dengan keadaan waktu, tempat dan kondisi sebagaimana kaidah: Perubahan hukum (dapat terjadi) berdasarkan perubahan masa, tempat dan keadaan ${ }^{29}$

Oleh karena itu yang abadi dan universal ialah dalam hukum waris Islam diantaranya norma tentang hak dan kedudukan anak laki-laki dan perempuan untuk mewarisi harta warisan orang tua. Sedangkan mengenai besarnya bagian dalam perbandingan laki-laki dan perempuan dalam segala tingkatan yang sederajat merupakan aturan batas yang dapat dilenturkan. ${ }^{30}$

Meski demikian, pada kenyataannya rumusan Pasal 176 KHI yang dijadikan hukum materil di lingkungan Peradilan Agama, ketentuan 2: 1 tidak bergeser. ${ }^{31}$ Ketentuan $176 \mathrm{KHI}$ yang tetap mempertahankan forsi $2: 1$ antara anak laki-laki dan anak perempuan dilatarbelakangi para penyusun ataupun ahli hukum Islam yang terlibat dalam penyusunan pasal $176 \mathrm{KHI}$ meyakini ketentuan ayat tersebut bersifat Sarih/tafsil dan gath'i, berdasarkan pada teori standar konvensional yang menyebutkan "perbedaan jumlah bagian anak perempuan dengan anak laki-laki berdasarkan hukum imbalan dan tanggung jawab", seperti yang telah diuraikan di atas. ${ }^{32}$

Dalam hukum waris Islam juga ditentukan bagian Ibu dan bapak yang berhak mewarisi bersama anak dengan keturunannya, dalam arti Ibu dan bapak sama-sama mewarisi dengan forsi yang berimbang, yakni sama-sama memperoleh 1/6 dari harta warisan, apabila pewaris meninggalkan anak laki-laki. Jika tidak ada, maka ibu mendapat $1 / 3$ dan untuk bapak sisanya $2 / 3$, karma bapak mempunyai kewajiban dan

\footnotetext{
${ }^{28}$ Zainuddin Sardar, Masa Depan Islam, (Bandung: Pustaka, 2017), hlm. 203 dan 342

${ }^{29}$ Jalaluddin Abdurrahman as-Suyuthi, AI Asybah wa an Nadhoir(Indonesia; Syirkah Nur Asia, t.th), hlm. 72.

${ }^{30}$ M. Mawardi Djalaluddin, Nilai-Nilai Keadilan dalam Harta Warisan Islam, hlm. 116

${ }^{31}$ Jalaluddin Abdurrahman as-Suyuthi, AI Asybah wa an Nadhoir, hlm. 121

${ }^{32}$ M. Mawardi Djalaluddin, Nilai-Nilai Keadilan dalam Harta Warisan Islam, hlm. 116
} 
tanggung jawab memberi nafkah untuk ibu. ${ }^{33}$

Walaupun dalam hukum waris Islam ditentukan forsi $1: 1$ (satu banding satu) antara bagian ayah dan bagian ibu, yakni sama-sama memperoleh 1/6 bagian, akan tetapi dalam pelaksanaannya/penerapannya masih memperhatikan keadilan atas dasar hak dan kewajiban, yakni beban dan tanggung jawab laki-laki lebih besar dibanding perempuan. ${ }^{34}$

Oleh karena itu akan dinilai adil jika bagian ayah lebih besar dibandingkan bagian ibu, seperti dalam kasus apabila pewaris meninggalkan ahli waris : suami, ibu dan bapak. Dalam kasus demikian, asal masalah adalah enam, dimana suami memperoleh $1 / 2$ (3 bagian), ibu memperoleh $1 / 3$ dari sisa ( 1 bagian) dan ayah mendapat sisa ( 2 bagian). ${ }^{35}$

\section{DASAR HUKUM WARIS ISLAM}

Dasar utama hukum waris Islam adalah Al-Qur'an dan Al-Hadis, khususnya menyangkut forsi atau bagian masing-masing ahli waris. Dalam QS. An-Nisa' ayat 11, 12 dan 176. Allah berfirman:

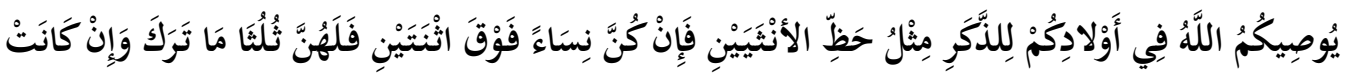

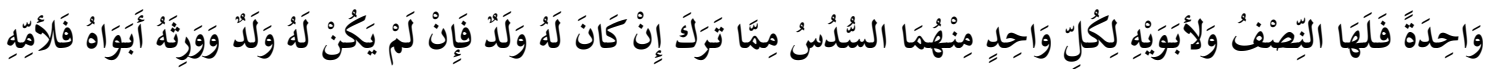

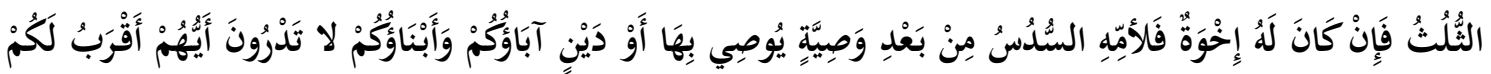

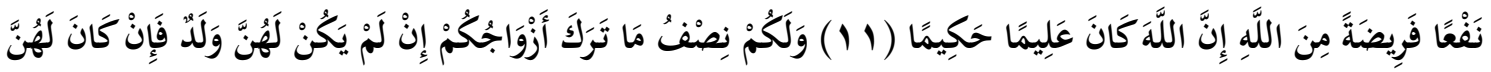

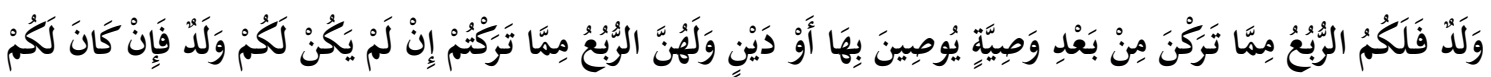

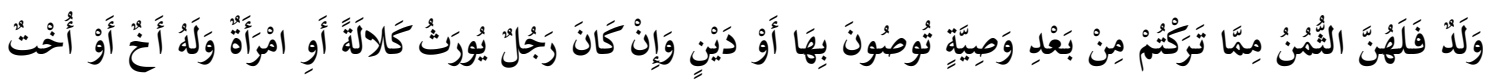

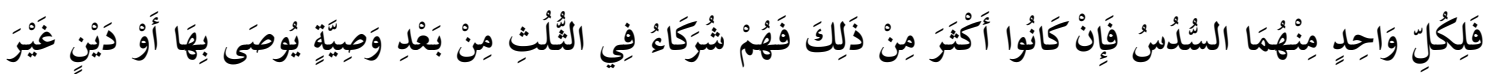

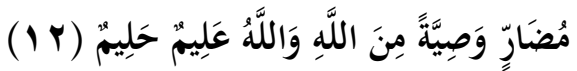

Artinya: Allah mensyari'atkan bagimu tentang (pembagian pusaka untuk) anakanakmu. Yaitu : bahagian seorang anak lelaki sama dengan bagahian dua orang anak

\footnotetext{
${ }^{33}$ Mahmud Yunus, Hukum Warisan dalam Islam, hlm. 92

${ }^{34}$ M. Mawardi Djalaluddin, Nilai-Nilai Keadilan dalam Harta Warisan Islam, hlm. 117

${ }^{35}$ M. Mawardi Djalaluddin, Nilai-Nilai Keadilan dalam Harta Warisan Islam, hlm. 117
} 
perempuan, ${ }^{36}$ dan jika anak itu semuanya perempuan lebih dari dua, ${ }^{37}$ Maka bagi mereka dua pertiga dari harta yang ditinggalkan; jika anak perempuan itu seorang saja, Maka ia memperoleh separo harta. dan untuk dua orang ibu-bapa, bagi masing-masingnya seperenam dari harta yang ditinggalkan, jika yang meninggal itu mempunyai anak; jika orang yang meninggal tidak mempunyai anak dan ia diwarisi oleh ibu-bapanya (saja), Maka ibunya mendapat sepertiga; jika yang meninggal itu mempunyai beberapa saudara, Maka ibunya mendapat seperenam. (Pembagian-pembagian tersebut di atas) sesudah dipenuhi wasiat yang ia buat atau (dan) sesudah dibayar hutangnya. (Tentang) orang tuamu dan anak-anakmu, kamu tidak mengetahui siapa di antara mereka yang lebih dekat (banyak) manfaatnya bagimu. ini adalah ketetapan dari Allah. Sesungguhnya Allah Maha mengetahui lagi Maha Bijaksana. Dan bagimu (suami-suami) seperdua dari harta yang ditinggalkan oleh isteri-isterimu, jika mereka tidak mempunyai anak. jika isteri-isterimu itu mempunyai anak, Maka kamu mendapat seperempat dari harta yang ditinggalkannya sesudah dipenuhi wasiat yang mereka buat atau (dan) seduah dibayar hutangnya. Para isteri memperoleh seperempat harta yang kamu tinggalkan jika kamu tidak mempunyai anak. jika kamu mempunyai anak, Maka Para isteri memperoleh seperdelapan dari harta yang kamu tinggalkan sesudah dipenuhi wasiat yang kamu buat atau (dan) sesudah dibayar hutang-hutangmu. jika seseorang mati, baik laki-laki maupun perempuan yang tidak meninggalkan ayah dan tidak meninggalkan anak, tetapi mempunyai seorang saudara laki-laki (seibu saja) atau seorang saudara perempuan (seibu saja), Maka bagi masing-masing dari kedua jenis saudara itu seperenam harta. tetapi jika saudara-saudara seibu itu lebih dari seorang, Maka mereka bersekutu dalam yang sepertiga itu, sesudah dipenuhi wasiat yang dibuat olehnya atau sesudah dibayar hutangnya dengan tidak memberi mudharat (kepada ahli waris). ${ }^{38}$ (Allah menetapkan yang demikian itu sebagai) syari'at yang benar-benar dari Allah, dan Allah Maha mengetahui lagi Maha Penyantun. ${ }^{39}$

Juga surah An-Nisa' ayat 176. Allah berfirman:

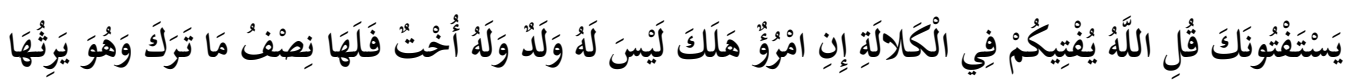

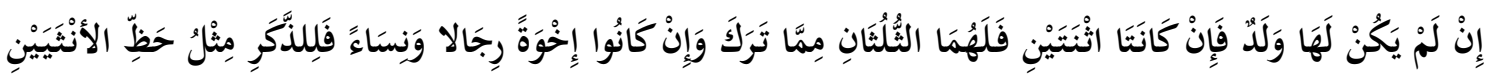

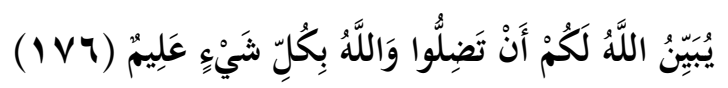

Artinya: Mereka meminta fatwa kepadamu (tentang kalalah). ${ }^{40}$ Katakanlah: "Allah memberi fatwa kepadamu tentang kalalah (yaitu): jika seorang meninggal dunia, dan ia tidak mempunyai anak dan mempunyai saudara perempuan, Maka bagi saudaranya yang perempuan itu seperdua dari harta yang ditinggalkannya, dan

\footnotetext{
${ }^{36}$ Bagian laki-laki dua kali bagian perempuan adalah karena kewajiban laki-laki lebih berat dari perempuan, seperti kewajiban membayar maskawin dan memberi nafkah. (Lihat surat An Nisaa ayat 34). ${ }^{37}$ Lebih dari dua Maksudnya : dua atau lebih sesuai dengan yang diamalkan Nabi

${ }^{38}$ Memberi mudharat kepada waris itu ialah tindakan-tindakan seperti: a. Mewasiatkan lebih dari sepertiga harta pusaka. b. Berwasiat dengan maksud mengurangi harta warisan. Sekalipun kurang dari sepertiga bila ada niat mengurangi hak waris, juga tidak diperbolehkan.

${ }^{39}$ Departemen Agama RI, Al-Qur'an dan Terjemahanya, hlm. 116-117

${ }^{40}$ Kalalah Ialah: seseorang mati yang tidak meninggalkan ayah dan anak.
} 
saudaranya yang laki-laki mempusakai (seluruh harta saudara perempuan), jika ia tidak mempunyai anak; tetapi jika saudara perempuan itu dua orang, Maka bagi keduanya dua pertiga dari harta yang ditinggalkan oleh yang meninggal. dan jika mereka (ahli waris itu terdiri dari) saudara-saudara laki dan perempuan, Maka bahagian seorang saudara laki-laki sebanyak bahagian dua orang saudara perempuan. Allah menerangkan (hukum ini) kepadamu, supaya kamu tidak sesat. dan Allah Maha mengetahui segala sesuatu. ${ }^{41}$

Ayat-ayat tentang kewarisan tersebut di atas merupakan ketentuan Allah secara umum ('Am) menyangkut siapa-siapa saja yang menjadi ahli waris berdasarkan hubungan kekerabatan seperti ayah, ibu, anak, dan saudara, ataupun karena hubungan perkawinan (suami/isteri). Selain dari pada itu juga menentukan tentang berapa besar bagian masing masing ahli waris dan langkah apa saja yang dilakukau sebelum menentukan harta peninggalan pewaris baru dikatakan sebagai harta warisan (terlebih dahulu menyelesaikan wasiat pewaris dan membayarkan utang pewaris). ${ }^{42}$

Selain itu, dalam ayat di atas juga digariskan bahwa forsi seorang laki-laki sama dengan forsi dua orang perempuan dalam satu tingkatan, baik dalam tingkatan anak, saudara ataupun antara suami dengan isteri. Diantara hukum waris Islam yang bersumber dari Hadis Nabi Muhammad Saw., adalah sebagaimana yang diriwayatkan dari Ibnu Abbas R.a yang artinya: "Nabi Muhammad Saw. bersabda: " Berikanlah harta pusaka kepada orang yang berhak. Sisanya untuk (orang) laki-laki yang lebih utama" ${ }^{43}$ Hadist tersebut mengatur tentang peralihan harta dari pewaris kepada ahli waris, setelah itu jika terdapat sisa, maka forsi laki-laki lebih besar dari forsi perempuan.

\section{KESIMPULAN}

Bertolak dari hasil pemaparan makalah di atas, maka penulis perlu kiranya memberikan kesimpulan pada penulisan makalah ini antara lain:

1) Azas " Keadilan berimbang", dalam hukum waris Islam menentukan laki-laki dan perempuan sama-sama berhak tampil sebagai ahli waris, dengan forsi yang berbeda.

2) Berdasarkan nash yang qath'i, maka adil dan berimbang yang dimaksudkan dalam hukum waris Islam adalah bagian laki-laki sama dengan bagian dua orang

\footnotetext{
${ }^{41}$ Departemen Agama RI, Al-Qur'an dan Terjemahanya, hlm. 153

${ }^{42}$ M. Mawardi Djalaluddin, Nilai-Nilai Keadilan dalam Harta Warisan Islam, hlm. 118

${ }^{43}$ M. Mawardi Djalaluddin, Nilai-Nilai Keadilan dalam Harta Warisan Islam, hlm. 118
} 
perempuan (forsi $2: 1$ antara laki-laki dan perempuan).

3) Perbedaan forsi tersebut tidak disebabkan persoalan gender, melainkan atas perbedaan tugas dan tanggung jawab yang dibebankan kepada laki-laki lebih besar dibandingkan dengan yang dibebankan kepada perempuan dalam konteks masyarakat Islam, sesuai teori standar konvensional yang menyebutkan: "Semakin besar dan berat beban yang dipikul seorang laki-laki, maka semakin besar pula hak yang akan diperolehnya", disebabkan biaya yang harus dikeluarkannya untuk mengemban tanggung jawab yang lebih besar.

\section{DAFTAR PUSTAKA}

Ahmad Rofik, Fiqh Mawaris, (Jakarta: PT. Raja Grafindo Persada, 2015)

Ahmad Zahari, Tiga Versi Hukum Kewarisan Islam: Syafi'i, Hazairin dan KHI, (Pontianak: Romeo Grafika, 2013)

Amir Syarifuddin, Pelaksanaan Hukum Kewarisan Islam dalam Lingkungan Adat Minangkabau, (Jakarta: PT. Gunung Agung, 2014)

Cholil Umam, Agama Menjawab Tantangan Berbagai Masalah Abad Modern, Surabaya: Ampel Suci, 2014)

Departemen Agama RI, Al-Qur'an dan Terjemahanya, (Semarang: Toha Putra, 2015) Idris Djakfar dan Taufik Yahya, Kompilasi Hukum Kewarisan Islam(Jakarta; PT. Dunia Pustaka Jaya, 2015)

Jalaluddin Abdurrahman as-Suyuthi, AI Asybah wa an Nadhoir(Indonesia; Syirkah Nur Asia, t.th)

M. Mawardi Djalaluddin, Nilai-Nilai Keadilan dalam Harta Warisan Islam, (Jurnal Volume V,Nomor 1,Januari-Juni, 2017)

Mahmud Yunus, Hukum Warisan dalam Islam, (Jakarta: PT. Hidakarya Agung, 2009) Masjfuk Zuhdi, Masail Fiqhyah, (Jakarta: PT. Gunung Agung, 2017) , Studi Islam, Jilid III, (Jakarta: PT. Raja Grafindo, 2013)

Muhammad Ali Ash-Shabuni, Ilmu Hukum Waris Menurut Ajaran Islam, (Surabaya: Mutiara Ilmu, t.th.)

Muhammad Amin Summa, Hukum Keluarga Islam di Dunia Islam, (Jakarta: PT. Raja Grafindo Persada, 2014) 
AL-'ADALAH: Jurnal Syariah dan Hukum Islam

e-ISSN: 2503-1473

Hal. 01-13

Vol. 4, No. 1, Juni 2019

Nashruddin Baidan, tafsir bi al-Ra yi, (Yogyakarta: Pustaka Pelajar, 2009)

Sayuti Thalib, Hukum Kewarisan Islam Di Indonesia, (Jakarta: Sinar Grafindo, 2015)

Zainuddin Sardar, Masa Depan Islam, (Bandung: Pustaka, 2017) 